\title{
Koncepcja kozła ofiarnego René Girarda jako inspiracja dla edukacji międzykulturowej
}

Streszczenie: W artykule zostaje przywołana koncepcja mimetyzmu i kozła ofiarnego autorstwa René Girarda. Zasada mimesis w ujęciu francuskiego intelektualisty stanowi fundament społecznej natury człowieka. Jako taka oznacza jednocześnie źródło społecznego cierpienia skutkującego kolektywną przemocą, jak i warunek ładu społecznego osiąganego za sprawą instytucji kozłów ofiarnych. Koncepcja kozła ofiarnego odwołuje się do czterech stereotypów, które składają się na schemat prześladowczy ukazujący przemoc jako specyficzną zasadę regulacji stosunków społecznych w sytuacji poważnego kryzysu społecznego. Zaprezentowane koncepcje zostały umieszczone w polu pytań, jakie stawiają współczesna pedagogika, edukacja międzykulturowa i krytyczna pedagogika religii.

Słowa klucze: René Girard, edukacja międzykulturowa, krytyczna pedagogika religii, mimesis, kozioł ofiarny, przemoc

\section{Wprowadzenie}

W centrum myśli, którą proponuje i rozwija w swych tekstach René Girard, stoi problem przemocy wpisanej w przestrzeń stosunków międzyludzkich. Na podstawie tekstów historycznych i literackich ów francuski historyk, filozof, krytyk literacki i antropolog rekonstruuje specyficzny schemat zachowań jednostki oraz relacji społecznych, które wiążą ją ze społecznością w sytuacji rozmaitych kryzysów. Chodzi tu o stanowiący podstawę koncepcji kozła ofiarnego tzw. schemat prześladowczy. Autor wskazuje w niej z jednej strony kluczową dla rozumienia społecznej natury człowieka zasadę mimetyzmu, z drugiej zaś - cztery kluczowe w omawianym ujęciu stereotypy konstytuujące ów schemat. Chodzi tu o „stereotyp ogólnego odróżnorodnienia charakterystycznego dla sytuacji kryzysu, stereotyp zbrodni »odróżnorodniających «, stereotyp stygmatów ofiarniczych oraz stereotyp przemocy" (Girard, 1991, s. 37). Gdy w określonych okolicznościach społecznych stereotypy te zaczynają się jeden po drugim ujawniać - dochodzi do wskazania przez 
społeczność kozła ofiarnego, a następnie kolektywnej przemocy na niego nakierowanej.

W niniejszym artykule przywołam wskazane elementy teorii R. Girarda analizowane i rozwijane przez niego w większości jego tekstów. Myśl francuskiego filozofa doczekała się bogatej literatury krytycznej. Zarzuty, jakie zwykle kierowano pod jej adresem, związane były z zastrzeżeniami wobec stosowanej przez autora metodologii oraz wynikających z niej nieuprawnionych roszczeń jego teorii do statusu prawd uniwersalnych (Girard m.in. utrzymywał i dowodził, że to właśnie przemoc leży u źródeł każdej tradycji religijnej $)^{1}$. Krytycy jednak zasadniczo nie podważali istoty koncepcji mimetyzmu ani mechanizmu kozła ofiarnego. Wydaje się również i dziś, że intuicje wyrażone w tych ujęciach dobrze korespondują z obserwacjami i badaniami prowadzonymi w ramach studiów kulturowych, w antropologii kulturowej, psychologii społecznej, w naukach politycznych i, co szczególnie $\mathrm{w}$ tym miejscu interesujące - w naukach o religiach. Większa część intuicji R. Girarda bierze bowiem swój początek w obserwacji zjawisk i procesów związanych z religią i religiami. O wymownych związkach przemocy z religią pisała w swej głośnej pracy ,Pola krwi. Religia i przemoc Karen Armstrong, podkreślając, że przemoc często rości sobie prawo do religijnego usprawiedliwienia (2017, s. 28). I tak, dla refleksji nad procesami i zjawiskami międzykulturowymi mającymi dziś często w swym tle konteksty religijne, nad globalnymi wyzwaniami współczesnych społeczeństw zachodnich mierzących się z rozmaitymi populizmami, narastającymi antagonizmami, nacjonalizmami, problemami dyskryminacji grup mniejszościowych, antysemityzmem, islamofobią, homofobią i wieloma innymi problemami społecznymi, koncepcje R. Girarda mogą stanowić ważny trop w poszukiwaniu i konstruowaniu pozytywnych rozwiązań teoretycznych i praktycznych w pedagogice i edukacji międzykulturowej. Wydaje się również, że szczególnie duży potencjał możliwości tkwi w krytycznej pedagogice religii, w ramach której problem przemocy, w tym również symbolicznej, może stać się centralnym przedmiotem uświadamiających oddziaływań edukacyjnych w duchu konstruktywnego oporu i emancypacji.

W dalszej części artykułu zaprezentuję najważniejsze wątki koncepcji R. Girarda, analizowane i rozwijane przez niego w większości jego tekstów.

1 Więcej na temat krytyki myśli R. Girarda zob. Urbańska-Szymoszyn, A. 2013. Mimesis i przemoc. U podstaw Girardowskiej teorii kształtowania się zjawisk kulturowo-społecznych. Rocznik Antropologii Historii. 2 (5), ss. 51-82. 


\section{Mimesis i schemat prześladowczy jako podstawy koncepcji kozła ofiarnego}

Jako teoretyczny kontekst dla tej koncepcji Tomasz Sikora w krytycznym posłowiu do książki R. Girarda Sacrum i przemoc przywołuje podjęty również i przez samego Girarda wątek ,,schizmogenezy”, czyli problemu zróżnicowania międzyosobniczego (Girard, 2019). Wątek ten pochodzi z teorii systemowej Gregory'ego Batesona, zgodnie z którą w sytuacji zmieniających się warunków określonego systemu, również społecznego, poszczególne elementy zaangażowane są w utrzymywanie jego równowagi. Środkiem, który temu celowi ma służyć, jest zapewniający komunikację między tymi elementami mechanizm sprzężenia zwrotnego (Pasikowski, 2016, ss. 370-371). Schizmogeneza zachodzi na drodze dwóch modalności: jako międzyludzkie przebiegi komunikacyjne zachodzące symetrycznie lub jako międzyludzkie przebiegi komunikacyjne zachodzące komplementarnie (Girard, 2019, s. 454).

W przypadku pierwszej relacja między dwoma podmiotami opiera się na równości - przykładem może być np. spór dziecięcy, przedstawiciele dwóch zwaśnionych rodów lub równoprawni uczestnicy wyścigu. W przypadku modalności komplementarnej w grę wchodzi asymetria kompetencji rozpoznawalna np. w relacjach dorosły-dziecko, lekarz-pacjent lub sędzia-podsądny. Tu wyraźna wydaje się funkcjonalna specjalizacja członków grupy spleciona z relacjami pokrewieństwa, władzy lub kompetencji kultycznych jako czynników wytwarzających społeczną hierarchię. Mechanizm sprzężenia zwrotnego inaczej będzie się wyrażał w pierwszym, a inaczej w drugim typie podsystemu społecznego. R. Girard, rozwijając teorię schematu prześladowczego i zbudowaną na nim koncepcję kozła ofiarnego, odnosi się w głównej mierze do modelu komplementarnego i charakterystycznej dlań asymetrii.

U podstaw koncepcji R. Girarda leży przekonanie o specyficznym, konstytuującym człowieka jako człowieka fundamencie ludzkiej natury, jakim jest posiadająca dwa oblicza zasada mimesis. Zasada ta stanowi jednocześnie źródło społecznego cierpienia skutkującego kolektywną przemocą, jak i warunek ładu społecznego osiąganego za sprawą instytucji kozłów ofiarnych. Dla R. Girarda mimetyzm rozumiany jako naśladowanie stanowi zasadę ewolucji człowieka, u którego genetyczne zachowania imitatywne mogły się rozwinąć w związku z intensywnym rozwojem jego mózgu. Sprzężenie to w toku ewolucji miało się przyczyniać do ciągłego wzrostu potrzeb, a tym samym do konieczności życia w grupie oraz stworzenia różnorodnych organizacji 
społecznych w celu lepszego i szybszego zaspokajania tych potrzeb i wymagań jednostek ${ }^{2}$. Kluczową motywacją ludzkich działań staje się w tym ujęciu pożądanie, będące funkcją skłonności naśladowczych człowieka. Człowiek nie tylko bowiem uczy się być, ale także uczy się mieć. Jak bowiem podkreśla R. Girard, w „zachowaniu człowieka nie ma niczego lub prawie niczego, co nie byłoby wyuczone, a każde uczenie się można określić jako imitację. Gdyby ludzie przestali nagle wzajemnie się naśladować, zaczęłyby stopniowo zanikać wszelkie formy kulturowe" (Girard, 1983, ss. 296-308). Mimesis, której człowiek uczy się w środowisku społecznym, to mimesis „przywłaszczania”. To przemożna siła pożądania i rywalizacji, która daje się wpisać w specyficzny, potrójny układ zależności, gdzie w triadzie: podmiot pożqdania - przedmiot pożądania - mediator pożądania mediator to ktoś drugi, rywal, który pożądając przedmiotu tak jak sam podmiot, podbija jego wartość. „Zawiść - wyjaśnia tę dynamikę R. Girard - nie posiadałaby tak niesłychanej władzy nad ludzkimi społecznościami, gdybyśmy nie mieli skłonności do wzajemnego naśladowania naszych pragnień. Zawiść to nic innego, jak owo wzajemne zapożyczanie pragnień w warunkach równości wystarczającej, aby zapewnić wzrost mimetycznej rywalizacji" (1992, s. 54). Ten mechanizm przypomina licytację: tym bardziej mi na czymś zależy, im bardziej zależy na tym komu innemu. Jako taki nabiera szczególnego znaczenia dopiero w sytuacji kryzysu.

Natomiast w sytuacji społecznej równowagi, dzięki wypracowanym mechanizmom kooperacji, dokonuje się w miarę harmonijna transmisja i reprodukcja biospołeczna, reprodukcja kultury. R. Girard, badacz mitów i archaicznych tradycji religijnych, równowagę taką wiąże z układaniem sobie przez daną społeczność stosunków z transcendencją w procesie ofiarniczym - tu system ofiarniczy traktowany jest jako gwarant ładu i spokoju społecznego. W sytuacji tej pozytywne doświadczanie zróżnicowania i wymiany wynika z naturalnej różnorodności realiów lub, jak można by to ująć - ze społecznego podziału wiedzy i pracy traktowanych jako oczywistość i naturalność świata życia.

Z chwilą jednak, gdy społeczność dotyka kryzys, gdy jej ekosystem ulega naruszeniu przez działanie katastrofy naturalnej lub społecznej, gdy „w społeczeństwie zaczyna się coś psuć, terminy płatności ulegają skróceniu, a zasada wzajemności uwidacznia się nie tylko w wymianach pozytywnych (...), lecz także w wymianach wrogich lub »negatywnych «, które wskazują tendencję wzrostową" (Girard, 1991, s. 23), dochodzi do niebezpiecznego, zagrażającego fundamentom spokojnego trwania społeczności odróżnorodnienia, do

2 Więcej na ten temat: Urbańska, A. 1997, ss. 21-45. 
ujawnienia się w pełnej krasie tego, co R. Girard ujmuje jako mimesis konfliktogenną.

Filozof opisuje ten proces w następujący sposób „(...) wszystkie różnice stopniowo się zacierają. Wszędzie panuje to samo pragnienie, ta sama nienawiść, ta sama strategia, to samo złudzenie dobroczynnego zróżnicowania w coraz bardziej kompletnej jednostajności. W miarę, jak kryzys utwierdza się, wszyscy członkowie wspólnoty stają się bliźniakami przemocy. Można powiedzieć, że stają się swoimi sobowtórami, odbiciem siebie samych" (Girard, 2019, s. 113). W sytuacji zagrożenia wszyscy zyskują wspólną pozycję wobec potencjału skutków kryzysu. Dotychczasowy podział na grupy wpływów i przywilejów, struktury społeczne, zawodowe i ekonomiczne przestaje obowiązywać. Wobec klęsk żywiołowych, wojny, epidemii, kryzysu gospodarczego społeczność traci swe cechy dystynktywne. Każdy w jednakowym stopniu zostaje zagrożony stratą lub unicestwieniem, wszyscy stają się równi wobec nadciągającej katastrofy.

W takich warunkach, jak dowodzi R. Girard, dochodzi do poszukiwania winnych kryzysu. Zwykle pojawia się wówczas społeczna tendencja tłumaczenia kryzysu uwarunkowaniami o charakterze etyczno-moralnym. Zamiast jednak ganienia samych siebie, ludzie zwykli przejawiać nieodpartą skłonność do udzielania nagany innym. Inni, w sytuacji kryzysu i załamywania się znanego i bezpiecznego świata życia, jawią się nie tyle jako podejrzani, co wprost zagrażający i niebezpieczni. Zaczyna dominować przekonanie, że nawet niewielka grupa „innych”, czasem nawet sama jednostka, pomimo względnej słabości może okazać się śmiertelnie niebezpieczna dla całej wspólnoty. Przekonanie to zaczyna być podzielane przez coraz większą część społeczności. W ten sposób wyłania się ważny dla koncepcji francuskiego myśliciela fenomen tłumu. „Tłum zawsze skłania do prześladowań - twierdzi R. Girard - bowiem naturalne przyczyny tego, co go turbuje (...) nie są w stanie go zainteresować. Tłum (...) dąży do działania, ale nie jest w stanie oddziaływać na przyczyny naturalne. Szuka więc przyczyny dostępnej, która mogłaby zaspokoić odczuwany przez niego głód przemocy. Jednostki składające się na tłum zawsze są potencjalnymi prześladowcami, bowiem marzy im się oczyszczenie wspólnoty z elementów nieczystych, które ją demoralizują, ze zdrajców, którzy ją podkopują" (1991, ss. 26-27). Tłum, jak rekonstruuje tę część koncepcji Girarda Anna Urbańska-Szymoszyn, przejawia tendencje do przejmowania funkcji instytucji lub stosowania presji wobec nich i wymuszania decyzji ku działaniu, ku kolektywnej przemocy (2013, s. 65). 
Mechanizm działania tłumu nadaje koncepcji Girarda rys pesymistyczny, a nawet defetystyczny - ludzie nie są w stanie stawić czoła nagiej bezsensownej przemocy bez ryzyka poddania się jej oddziaływaniu. Zwykle, na co dzień, nie doceniali jej w pełni. Teraz, w sytuacji kryzysu to ona właśnie wydaje się im jedynym dostępnym i skutecznym sposobem rozprawienia się z tymi, którzy w ich przekonaniu odpowiadają za kryzys. Wraz z konstytuowaniem się tłumu upadają społeczne struktury. Zawieszeniu ulega obowiązująca dotąd tzw. zasada różnic definiująca wcześniej społeczny porządek, ów wskazywany już społeczny podział wiedzy i pracy. Pomieszaniu ulegają akceptowane dotąd hierarchie wartości, funkcje oraz struktury społeczne. W kryzysie uruchamia się za to mechanizm odróżnorodnienia przez wzajemność: elementy wzajemności, dotąd zakryte, ulegają odsłonięciu i przekształcają się w tzw. złą wzajemność. Ta, z jednej strony przeciwstawia sobie ludzi, z drugiej jednak - ujednolica ich zachowania. „Każdy bowiem, walcząc przeciwko drugiemu, zachowuje się w podobny, agresywny sposób i stosuje podobne środki przeciw rywalom. Zło wciąż wzrasta, a identyczność zachowań wywołuje wrażenie pomieszania, totalnego odróżnorodnienia. Tłum z chwilą zmobilizowania ma najwyższą władzę. Zmusza wszystkie instytucje, aby się weń wtopiły. (...) W czasie kryzysu tłum jest jak tygiel, w którym wszystko się stapia - i władze, i autorytety" (Urbańska-Szymoszyn, 2013, s. 65).

Ten powyższy automatyzm oskarżeń kierowanych przeciwko wspólnemu wrogowi, kozłowi ofiarnemu, spleciony z prześladowczymi przedstawieniami i działaniami, składa się na drugi i trzeci ze wskazanych przez autora stereotypów, na oskarżycielski stereotyp „zbrodni odróżnoradniających” oraz stereotyp związany ze specyficznymi stygmatami ofiarniczymi. Aby obciążyć ofiary odpowiedzialnością za kryzysowe „odróżnorodnienie”, oskarża się je o „odróżnoradniające” zbrodnie. Stereotyp związany z wyborem ofiar wydaje się szczególnie interesujący dla refleksji prowadzącej nas ku problemom międzykulturowości i pedagogiki międzykulturowej.

Co bowiem decyduje o wskazaniu winnego? Co przesądza o identyfikacji kozła ofiarnego? Pozornie piętna, owe stygmaty, znaki ofiarnicze wydają się związane z tym, co posiada charakter różnicujący. Jako wroga zwykle wskazuje się bowiem mniejszość - etniczną, religijną, seksualną, polityczną, związaną z niepełnosprawnościami lub jakiegokolwiek innego rodzaju. „Nie ma społeczności - utrzymuje R. Girard - która nie poddawałaby swojej mniejszości, swoich niedostatecznie zintegrowanych bądź tylko wyróżniających się grup, pewnym formom jeśli nie prześladowań, to co najmniej dyskryminacji” (1991, s. 29). Jednak znaki kulturowe również mają taki, różnicujący charak- 
ter. Jest zatem, zdaniem filozofa, zasadnym mieć na uwadze istnienie dwóch sposobów różnienia się, dwóch typów zróżnicowania (Girard, 1991, s. 34). $Z$ jednej strony istnieje bowiem naturalne zróżnicowanie wewnątrz danego systemu - dzięki niemu przecież rozpoznajemy granice kultur, również własnych, nie tracąc przy tym poczucia własnej indywidualności w ramach partykularnego systemu kulturowego. System ten w zwyczajny, codzienny sposób podtrzymuje owo poczucie ,inności” wśród pozostających w jej kręgu jednostek. Znaki ofiarnicze muszą więc odnosić się do innego typu zróżnicowania.

To różnica pozasystemowa przeraża, to ona sugeruje prawdę o rodzimym systemie, o jego względności, kruchości, śmiertelności. Kozłem ofiarnym bywa człowiek przybyły „z zewnątrz”, uznany za obcego lub obcokrajowca. Być może „uczynił coś, czego czynić nie należy; jego zachowanie zostało uznane za szkodliwe; jakiś jego gest został źle zinterpretowany" (Girard, 1991, s. 50). Paradoksalnie jednak to nie z ich własnej „inności” czyni się zarzut mniejszościom religijnym, etnicznym, narodowym, lecz z przekonania, że różnią się za słabo, nie różnią się jak trzeba, a w krańcowym przypadku, być może - że nie różnią się wcale. Kategorie ofiarnicze wydają się predysponować do popełniania zbrodni odróżnorodniających. Etnocentryczne roszczenia wobec „innego” prowadzą do przeświadczenia, że w porównaniu „ze mną" inny jest niedostateczny, że nie jest „w normie”. „Obcokrajowcy dowodzi R. Girard - nie są zdolni do respektowania »prawdziwych « różnic; albo nie mają właściwych nawyków, albo właściwego gustu; niewłaściwie pojmują inność jako taką (...) To nie inne nomos widzi się w innym, lecz anomalię, nie inną normę, lecz anormalność; ułomność staje się szpetotą; obcokrajowiec - apatrydą" (1991, ss. 34-35). R. Girard wskazuje w tym kontekście na prześladowcze zniekształcenia, na tendencję do ukazywania tych „anormalności" jako cech monstrualnych fizycznie lub/i moralnie. Dzięki takim zniekształcającym strategiom łatwiej uznać, że rozpoznawalne w "obcym” kategorie ofiarnicze stanowią oskarżenie „mojej własnej” kultury. Nie tylko bowiem jej nie przekraczają (wtedy można byłoby je zaklasyfikować jako bezpiecznie odległe, niezwiązane „ze mną”, odrębne, bezpieczne), ale także, co gorsza, stanowią subiektywnie „przeze mnie” postrzegane i obraźliwe jej wynaturzenie, ułomność i defekt. Mówią niejako „z samego wnętrza mimetyzmu" (Girard, 2018, s. 149), mimetyzmu konfliktogennego. Dlatego też, jak konkluduje autor koncepcji kozła ofiarnego, wbrew pozorom to nie różnica staje się przyczyną obsesji prześladowców. Jest nią właśnie jej przemilczane przeciwieństwo: zatarcie się różnicy. 
Ostatnim stereotypem, który w swej koncepcji rozważa R. Girard, jest kolektywna przemoc będąca zwieńczeniem schematu prześladowczego, w oparciu o który zbudowana zostaje koncepcja kozła ofiarnego. Jako ilustrację i potwierdzenie dla swoich rozważań francuski historyk i badacz mitów przywołuje w swych tekstach wiele ilustracji historycznych i wątków mitologicznych. W tekście Kozioł ofiarny (Girard, 1991) analizuje m.in. relacje czternastowiecznego francuskiego poety Guillama de Machut dotyczące masakr dokonywanych na Żydach, których oskarżano winą za doprowadzenie do epidemii dżumy. Zarzucano im zatruwanie źródeł wody i sprowadzenie na Francję bożego gniewu w postaci zarazy. Filozof analizuje również przypadek polowań na czarownice oraz mity, np. mit o Edypie, w którego losach ogniskuje się całokształt mechanizmu kolektywnej przemocy. W książce Dawna droga, którą kroczyli ludzie niegodziwi (Girard, 1992) analizuje przypadek biblijnego Hioba jako ofiary kolektywnej przemocy powodowanej zawiścią jego przyjaciół. W tekście Widziałem szatana... (Girard, 2002) odnosi się do przykładów zbiorowego uśmiercania ofiar w tekstach biblijnych i ewangelicznych. Wszystkie przywoływane przezeń ilustracje ukazują ten sam, wynikający z sekwencji następujących po sobie, w gruncie rzeczy zupełnie irracjonalnych stereotypowych przesłanek, schemat prześladowczy. „Dzięki prześladowczemu mechanizmowi kolektywny niepokój i frustracja doznają zastępczego zaspokojenia w prześladowaniach ofiar, przeciw którym można zawrzeć przymierze z racji ich przynależności do niedostatecznie zintegrowanych mniejszości. (...) Termin »kozioł ofiarny« określa równocześnie niewinność ofiary, kolektywną nienawiść, jaka się na niej skupia oraz kolektywnie realizowany efekt owej nienawiści. Prześladowcy zamykają się w »logice« prześladowczego przedstawienia i nie mogą się już z niej wydobyć. (...) Proces prześladowczy wywiera tak silny nacisk na indywidua poddane jego działaniu, że ofiary nie mają szans, aby wykazać swoją niewinność” (Girard, 1991, ss. 62-63). Kolektywna przemoc skierowana na kozła ofiarnego rozładowuje grupowe niepokoje związane z sytuacją kryzysu. W zwieńczeniu tej logiki R. Girard uwzględnia jeszcze jeden, ostatni etap, etap sakralizacji ofiary, a dokładnie - procesu wytwarzania przez nią sacrum. Jest to etap mitologizujący całość schematu prześladowczego - poprzez akt kolektywnej przemocy odwróceniu ulega układ pomiędzy prześladowcami a ich ofiarą i to odwrócenie właśnie staje się źródłem sacrum. Czyni z biernej wszak ofiary przedmiot wiary we wszechmoc instytucji kozła ofiarnego jako instytucji przebłagalnej, zażegnującej kryzys - dzięki niemu udaje się odzyskać poczucie kolektywnej jedności i uzyskać stan zbawczego pokoju. Jest zatem kozioł ofiarny figurą 
ambiwalentnego nacechowania. Postacią niewinnie skazaną i tragiczną. Instytucją paradoksalną i nieszczęsną. A przy tym - gwarantem odtwarzającego się po katastrofie ładu społecznego. Tak oto opisuje ową zaskakującą „obrotowość" stanowiącej podstawy schematu prześladowczego zasady mimesis sam filozof: „Czynnik ten stanowi praprzyczynę moralnego i fizycznego cierpienia ludzi, tragicznych i groteskowych nieporozumień, a w konsekwencji wszelkiego nieładu. Jednak mimetyzm jest także przyczyną wszelkiego ładu ustanawianego za pośrednictwem kozłów ofiarnych, ofiar przynoszących spontaniczne pojednanie. Ofiary te zespalają bowiem przeciwko sobie w finalnym i zawsze mimetycznym, choć jednomyślnym, paroksyzmie wszystkich ludzi, którzy byli ze sobą skłóceni na skutek uprzednich, z początku nie tak jeszcze gwałtownych efektów mimetycznych" (Girard, 1991, s. 241). Ten głęboko antropologiczny i ze wszech miar międzykulturowy wniosek niestety nie napawa optymizmem.

\section{Podsumowanie}

Logika przemocowej konieczności jako drogi do stabilizacji ładu społecznego i pokoju daje do myślenia. Współczesny kontekst globalnych sporów, sporów idei i wartości, praktyk społecznych, rozstrzygnięć politycznych i ekonomicznych, migracyjnych i ekologicznych, to kontekst, w którym wielkie, ogólnoświatowe tematy coraz częściej przekładają się na naszą bezpośrednio doświadczaną codzienność. Generują coraz to nowe konflikty i kryzysy, nie są neutralne etycznie, skłaniają do zaangażowania, do podejmowania decyzji. Czy twarda lekcja, jaką daje nam René Girard, jest w stanie uczynić nas bardziej świadomymi zagrożeń? Czy sprawi, że staniemy się czujni i wrażliwsi? Czy pomoże nam wyzbyć się mechanizmu „prześladowczej nieświadomości” po to, by skuteczniej omijać dramatyczne ścieżki przemocowych schematów? R. Girard przy całym pesymizmie własnych teorii pozostawia nam bardzo słaby, ale jednak cień nadziei: „Zostaliśmy zanurzeni w mimetyzm. Niektórzy mają szczęście posiadać dobre wzorce i wiedzę dotyczącą możliwości wycofania się i zdobycia dystansu. Inni nie mają tego szczęścia i posiadają złe wzorce" (2018, s. 177). Skoro nie sposób wyeliminować samego mechanizmu mimetycznego stojącego za przekleństwem stereotypów prześladowczych, warto przynajmniej w jego ramach nieustannie podejmować próby edukacji wspierającej krytyczną samoświadomość, rozumienie siebie i innych oraz rozwój kompetencji komunikacyjnych. 
Wciąż, jak się wydaje, słabo rozpoznane pozostają w tym kontekście edukacyjne możliwości, jakie niesie ze sobą krytyczna pedagogika religii, której założenia sformułowano w Niemczech w latach siedemdziesiątych. Bogusław Milerski przywołuje ważną dla rozumienia jej celów wypowiedź jednego z jej promotorów: „Religia chrześcijańska i marksistowska teoria społeczna mają jeden wspólny pogląd, że świat, w którym żyjemy nie jest najlepszym z możliwych światów, lecz jest targany sprzecznościami, konfliktami i wrogością. Młodzież w naszym społeczeństwie w sposób oczywisty wzrasta w obliczu różnorodnych rodzajów ujawniania się władzy, przemocy i terroru. Dążenie do przekazania młodzieży, nawet jeśli tylko cząstkowo, iluzji świętego świata, oznaczałoby zgodę na nierzetelne przygotowanie do życia (...). Dlatego wychowanie [również religijne] nigdy nie może być wystarczająco krytyczne. Przede wszystkim wobec wielkich słów, wychwalanych wartości czy głoszonych ideologii krytyczne rozstrzygnięcia stają się koniecznością. Religijne wychowanie, a wraz z nim lekcje religii, mają za zadanie uczynić młodych ludzi odpornymi wobec dominujących sił i ideologii. Drugie przykazanie dekalogu (...) jest krytyczną zasadą sprzeciwiającą się wszystkim tendencjom absolutyzacji i ubóstwienia. Wiara chrześcijańska nie zawsze pozostawała temu wierna i sama przekształciła się w ideologię. (...) Zamiast stawać po stronie gnębionych, często sprzysięgała się z gnębicielami. Tym bardziej jest konieczna reaktywacja krytycznego potencjału tradycji religijnej. Krytyczne nauczanie religii może wnieść bowiem wkład do niezbędnego otrzeźwienia, wglądu w prawdziwą sytuację, do analizy krytycznej i w takim samym stopniu do zaangażowania na rzecz tworzenia ludzkich relacji w naszym społeczeństwie" (2011, s. 162). Zadania krytycznej pedagogiki religii koncentrują się zatem wokół edukacji do krytycznej samoświadomości jednostek i rozwijania ich emancypacyjnych kompetencji. Wśród kompetencji tych na szczególną uwagę zasługiwać powinny umiejętności demaskowania form przemocy symbolicznej obecnych w obowiązujących jako dogmatyczne, ortodoksyjnych interpretacjach tekstów kultury oraz praktykach religijnych. Ważne jest również wychowanie i edukowanie do zaangażowania na rzecz zmiany warunków społecznych będących na mocy religijnych legitymizacji wykluczającymi i opresyjnymi. W świetle pesymistycznych koncepcji R. Girarda takie działania edukacyjne wydają się nie tylko pożądane, ale przede wszystkim konieczne. 


\section{Bibliografia}

Armstrong, K. 2017. Pola krwi. Religia i przemoc. Warszawa: WAB.

Girard, R. 1983. Rzeczy ukryte od założenia świata. Literatura na Świecie. 12, ss. 296-308.

Girard, R. 1991. Kozioł ofiarny. Łódź: Wydawnictwo Łódzkie.

Girard, R. 1992. Dawna droga, która kroczyli ludzie niegodziwi. Warszawa: Wydawnictwo Spacja.

Girard, R. 2002. Widziatem szatana... Warszawa: Instytut Wydawniczy PAX. Girard, R. 2018. Apokalipsa tu i teraz. Rozmawiał Benoit Chantre. Kraków: WAM.

Girard, R. 2019. Sacrum i przemoc. Kraków: Nomos.

Milerski, B. 2011. Hermeneutyka pedagogiczna. Perspektywy pedagogiki religii. Warszawa: ChAT.

Pasikowski, P. 2016. Między schizmogenezą a holizmem. Próby rekonstrukcji instrumentów cybernetycznej metodologii Gregory'ego Batesona. W: Jaworska-Witkowska M. i Witkowski, L. red. Humanistyczne wyzwania ekologii umystu: Gregory Bateson w Polsce. Warszawa: Fundacja na rzecz Myślenia im. Barbary Skargi, ss. 370-371.

Sikora, T. 2019. Posłowie: Moc czy przemoc - teoria Rene Girarda z perspektywy systemowej. W: Girard, R. Sacrum i przemoc. Kraków: Nomos, ss. 454-459.

Urbańska, A. 1997. Koncepcja mimesis Rene Girarda. Etnografia Polska. 41, z. 1-2, ss. 21-45.

Urbańska-Szymoszyn, A. 2013. Mimesis i przemoc. U podstaw Girardowskiej teorii kształtowania się zjawisk kulturowo-społecznych. Rocznik Antropologii Historii. 2 (5), ss. 51-82.

\section{René Girard's concept of scapegoat mechanism as an inspiration for intercultural education}

Abstract: The article is focused on the recalls of the concept of mimetism and scapegoat by René Girard. In the view of the French intellectual, the mimesis principle lays the foundation for human social nature. As such, it entails both the source of social suffering resulting from collective violence and the condition of social order achieved through the institution of scapegoats. The concept of scapegoat refers to four stereotypes that make up the persecution scheme presenting violence as 
a specific principle of regulating social relations in serious social crisis. The presented concepts have been centered around the questions posed by contemporary pedagogy, intercultural education and critical pedagogy of religion.

Keywords: René Girard, intercultural education, critical pedagogy of religion, mimesis, scapegoat, violence

Translated by Monika Humeniuk 